\title{
A Method for the Calculation of the
}

\section{Relative Contributions of Recruitment}

\section{and Enhancement to Human Eccrine Sweating}

\author{
Juan Carlos Fasciolo, Gregory L. Totel, Becky B. Johnson, and \\ ROBERT E. JOHNSON \\ From the Human Environmental Research Unit, Department of Physiology and \\ Biophysics, University of Illinois, Urbana, Illinois 61801
}

\begin{abstract}
A B S T R A C T The rate of eccrine sweating has been studied by collecting samples in unventilated capsules from human subjects following subdermal or intradermal injections of acetyl- $\beta$-methylcholine and under moderate total body heat exposure. The rate of sweating in a given area of skin could increase by recruitment of fresh glands, enhanced output of the already active glands, or some combination of both.

A theoretical analysis shows how recruitment and enhancement can be calculated separately, assuming the existence of a maximal rate of sodium reabsorption by eccrine sweat glands, a sodium concentration of 145 $\mu \mathrm{Eq} / \mathrm{ml}$ in the precursor fluid, the absence of significant water reabsorption, and the absence of back-diffusion of sodium. The results indicate that, depending on the experimental conditions, an increased rate of sweating can be attributed mainly to recruitment, to enhancement, or to a combination of both.
\end{abstract}

\section{INTRODUCTION}

Human eccrine sweat appears to be formed from an isotonic or slightly hypertonic precursor fluid, from which sodium and chloride are reabsorbed to leave a hypotonic sweat (1-3). According to Brusilow (4) the precursor fluid is initially hypertonic but is made isotonic later on by the diffusion of water into the lumen of the proximal portion of the sweat gland.

This work was presented in part at the annual meeting of the American Society for Clinical Investigation, May 1969.

The permanent address of Dr. Fasciolo is the Departmento de Fisiologia, Universidad Nacional de Cuyo, Mendoza, Argentina.

Dr. B. Johnson held a postdoctoral fellowship from the National Institutes of Health.

Received for publication 22 July 1969 and in revised form 29 December 1969.
The reabsorption of sodium appears to be an active process of limited capacity, so the sodium reabsorption rate of a population of glands will remain constant once the saturation point has been reached (4-8). In symbols, sodium reabsorption at its maximum becomes Tma .

The sodium reabsorption rate $\left(\mathrm{Na}_{\text {reab }}\right)$ for any given sweat gland population can be calculated as follows: $\mathrm{Na}_{\text {reab }}$ rate $=\left(145-[\mathrm{Na}]_{\mathrm{sw}}\right) \mathrm{Vol}_{\mathrm{sw}}$ rate. The postulates, identities, and assumptions upon which this equation is based are summarized in Fig. 1. The first assumption is that the sodium concentration of the precursor fluid $[\mathrm{Na}]_{\text {prec }}$ is at or near isotonicity with plasma (145 $\mu \mathrm{Eq} / \mathrm{ml})$. This is based on the investigations of Cage and Dobson (1), Bulmer and Forwell (6), and others. Cage and Dobson studied the slope of the resulting curve when the rate of $\mathrm{Na}$ excretion per unit area was plotted against the sweat rate per unit area. They took this slope to be the [Na] of the precursor fluid. In six subjects, the average value for the $[\mathrm{Na}]_{\text {prec }}$ was 137.8 $\mathrm{mEq} /$ liter. Bulmer and Forwell (6), by extrapolating the sodium concentration to infinite sweat rate, also concluded that the precursor fluid is generally in the isotonic range. Additional evidence indicating that the precursor fluid is not hypotonic is provided by Brusilow (4) and Slegers (9). They found slightly hypertonic values for this fluid by determining the freezing point depression on frozen microsections. However, if the precursor fluid is hypertonic instead of isotonic, then the calculated Nareab rate will be below the actual Nareab rate by a value equal to the difference between 145 and the actual $[\mathrm{Na}]_{\text {prec. }}$

The second assumption is the absence of significant water reabsorption from the hypotonic sweat inside the double-layered distal portion of the sweat duct into the surrounding isotonic interstitial medium. This portion of the sweat duct has generally been thought to be relatively impermeable, by analogy with the collecting 


\section{POSTULATES \& IDENTITIES.}

$$
\begin{aligned}
& \text { (1) } \mathrm{Na}_{\text {reab }}=\mathrm{Na} \text { prec }-\mathrm{Na}_{\text {sweot }} \\
& \text { (2) } \mathrm{Na}_{\text {prec }}=[\mathrm{Na}]_{\text {prec }} \times \mathrm{Vol}_{\text {prec }} \\
& \text { (3) } \mathrm{Na}_{\text {sweot }}=[\mathrm{Na}]_{\text {sweat }} \times \mathrm{Vol}_{\text {sweot }} \\
& \text { (4) } \mathrm{Vol}_{\text {prec }}=\mathrm{Vol} \text { sweat }
\end{aligned}
$$

ASSUMPTIONS:

(1) $[\mathrm{Na}]_{\text {prec }}=145 \mu \mathrm{Eq} / \mathrm{ml}$

(2) No significant $\mathrm{H}_{2} \mathrm{O}$ reabsorption

(3) No back-diffusion of sodium

$$
\begin{aligned}
& \text { THEREFORE: } \\
& \mathrm{No}_{\text {reab }}=\left(145-[\mathrm{Na}]_{\text {sweat }}\right) \times \mathrm{Vol}_{\text {sweat }}
\end{aligned}
$$

Figure 1 Postulates, identities, and assumptions involved in deriving equation for $\mathrm{Na}$ reabsorption rate by eccrine sweat gland.

duct of the kidney. However, direct experimental evidence on this aspect of sweat gland function is scanty. The analogy with the nephron is strengthened by the demonstration by Fasciolo, Totel, and Johnson (10) that antidiuretic hormone ( $\mathrm{ADH})$ can inhibit sweating when introduced subdermally. It is also true that the urea concentrations in sweat are consistently in excess of those in plasma and have been interpreted by Schwartz, Thaysen, and Dole (11) and others (12) as evidence for reabsorption of water from the sweat duct. An alternate explanation to this finding, as Gordon and Cage point out (13), is that the urea is secreted somewhere within the sweat duct. This problem remains unsolved. If some water reabsorption does occur, then the calculated $\mathrm{Nareab}$ rate will be lower than the actual Nareab rate by a factor directly proportional to the rate of water reabsorption.

The third assumption is the absence of any significant $\mathrm{Na}$ back-diffusion from the surrounding interstitial fluid into the hypotonic sweat in the duct. There is no evidence, to our knowledge, supporting or denying this possibility. However, in the event that there is backdiffusion of sodium through the membrane, the calculated Nareab rate will again be lower than the actual $\mathrm{Na}$ reab rate in proportion to the rate of $\mathrm{Na}$ backdiffusion.

Obviously, our assumptions refer to an idealized model of sweat gland function. In actual fact some water reabsorption may indeed take place. But the quantitative aspects of the implications involved in these assumptions are both beyond the scope of this paper and unnecessary for the expressed purpose. If the values of these factors (i.e. [Na $]_{\text {prec, }}$ water reabsorption rate, and $\mathrm{Na}$ backdiffusion rate) for a sweat gland population remain relatively constant, this approach to studying sweat gland participation remains valid since the conclusions are based on per cent change in calculated $\mathrm{Nareab}$ rate and per cent change in measured sweat rate.

When the capacity of the sweat duct to reabsorb $\mathrm{Na}$ reaches a maximum $\left(\mathrm{T}_{\mathrm{Na}}\right)$, the $\mathrm{Na}$ reabsorption rate will remain constant despite any increase in sweat rate. Consequently, an increase in sweat rate by this population (defined as enhancement) will necessarily result in an increase in the $[\mathrm{Na}]=\mathrm{w}$ as shown in Fig. 2. On the other hand, when an increase in sweat rate is accompanied by a proportional increase in the rate of $\mathrm{Nareab}$, the $[\mathrm{Na}]_{\mathrm{sw}}$ must remain constant. Assuming $\mathrm{Tm}_{\mathrm{Na}}$ has already been reached, the constant $[\mathrm{Na}]_{\text {ow }}$ cannot be the result of any increase in Nareab by the already active population but must be due to the involvement of new sweat glands (defined as recruitment) (See Fig. 3).

This same concept between the per cent increase in $\mathrm{Na}$ reab rate and the per cent increase in sweat rate is a measure of the population recruited. A ratio of 1.00 indicates that all the increase in sweat rate is brought about by recruitment, while values between 0.00 and 1.00 indicate the relative participation of enhanced populations as well as recruited. As the ratio decreases, the percentage contribution due to enhancement increases.

If $\mathrm{Na}$ reab rates are calculated for various sweat rates and plotted as a function of sweat rate, then a straight line passing through the origin is obtained for recruited populations (Fig. 4). This line will predict the increase in Nareab when all the increase is due to recruitment. The slope of the line is 0 when all the increase is due to enhancement.

This type of analysis may provide a useful index for the relative participation of different sweat gland populations for various sweat rates.

\section{METHODS}

Mode of sweat stimulation. Three different methods were used to elicit sweating.

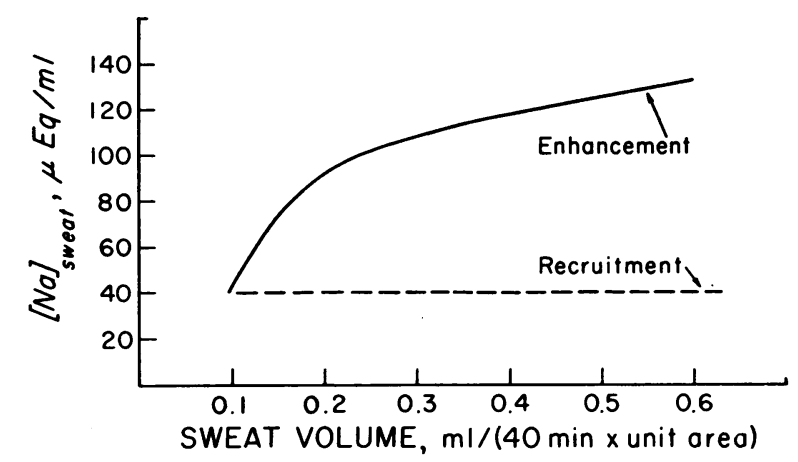

FIGURE 2 Predicted changes in $[\mathrm{Na}]_{s w}$ with increasing sweat rate given an initial $[\mathrm{Na}]_{\mathrm{s}}$ of $40 \mu \mathrm{Eq} / \mathrm{ml}$ and an initial sweat rate of $0.1 \mathrm{ml}$. Enhancement contrasted with recruitment. Constant $\mathrm{Na}_{\text {reab }}$ is assumed for enhancement, reabsorption proportional to the sweat rate for recruitment. 


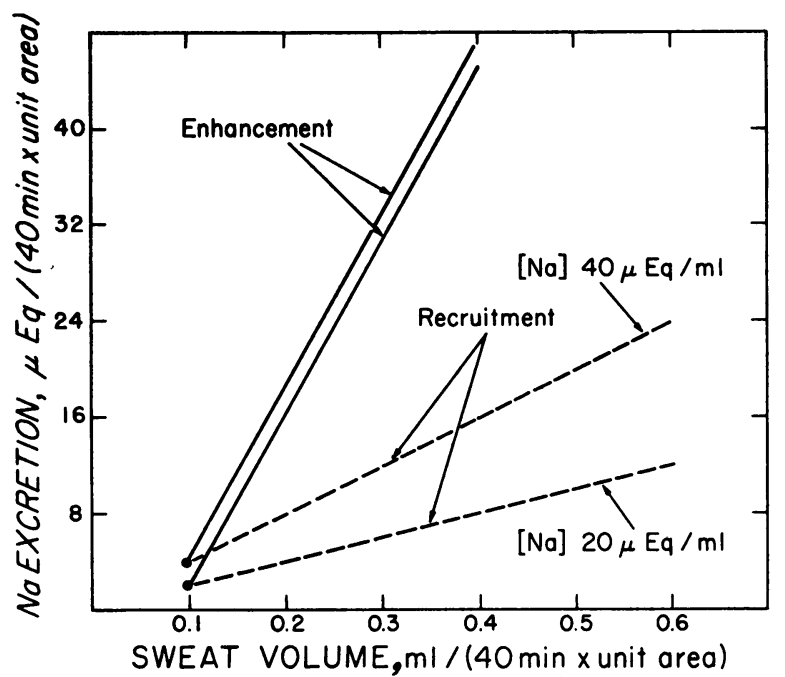

FIgURE 3 Predicted sodium excretion in sweat, plotted against sweat rate, for increases in rate due to recruitment or enhancement. In the first case, the reabsorption of sodium will increase with the number of units recruited and the [Na] in sweat will remain constant. Straight lines are obtained passing through the origin and their slopes are a function of the $[\mathrm{Na}]_{\mathbf{s w}}$. For enhancement, the increase in sweat rate is brought about by an increase in the rate of formation of the precursor fluid, but the reabsorption of sodium must remain constant. Consequently the $[\mathrm{Na}]_{\mathrm{sw}}$ increases with sweat rate. Parallel straight lines for sodium excretion with positive $X$-intercepts are obtained for populations of glands with different initial $[\mathrm{Na}]_{\mathbf{s w}}$.

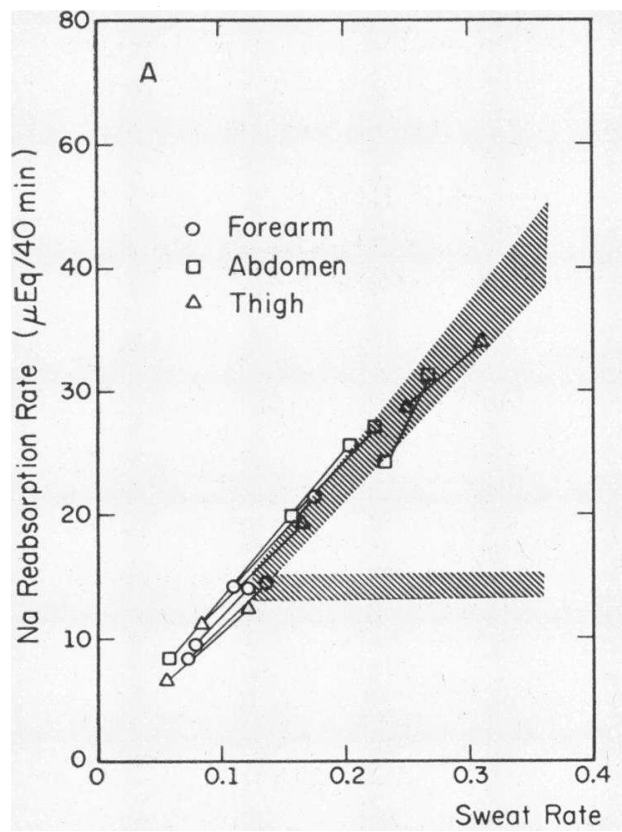

The first method was total body heat exposure. It consisted of seating the subject in a heat chamber with conditions at $40^{\circ} \mathrm{C}$ dry bulb, $24^{\circ} \mathrm{C}$ wet bulb, and $20 \%$ relative humidity. Experiments were conducted with three male subjects, all in good health.

The second method was the subdermal injection of $3 \mathrm{ml}$ of $\mathrm{Mecholyl}^{1}$ (acetyl- $\beta$-methylcholine $\mathrm{HCl}$ ) at $200 \mu \mathrm{g} / \mathrm{ml}$ while the subject was lying in bed in an air conditioned room at $24^{\circ} \mathrm{C}, 40 \%$ relative humidity. Three experiments were performed with two healthy male subjects. A description and validation of the subdermal injection technique is given by Fasciolo, Totel, and Johnson (10).

Daily intradermal injections of Mecholyl provided the third method of sweat induction. Training of the sweat glands at a selected site on the forearm was accomplished by the method of Collins, Crockford, and Weiner (14). Two intradermal injections of $100 \mu \mathrm{g}$ of Mecholyl in $0.5 \mathrm{ml}$ of isotonic saline were given daily with $1 \mathrm{hr}$ between injections. Four subjects (two men and two women) continued training for 18 days.

Sweat collection. Sweat was collected on filter papers in an unventilated capsule (8). The filter paper to be used (Whatman filter paper, No. 1) was boiled twice in distilled water, rinsed several times with cold distilled water, and dried in a vacuum oven. This was done in order to remove as much innate $\mathrm{Na}$ and $\mathrm{Cl}$ as possible from the filter paper. Immediately before collection began, the chosen area of skin was washed with distilled water and dried. To collect the sweat, two circular pieces of filter paper (area $=14.3 \mathrm{~cm}^{2}$ each) were held firmly to the skin by means of an unventilated aluminum capsule and elastic straps at each site of collection. At the end of each period of sweat collection, the filter paper was removed and placed in numbered, air-

${ }^{1}$ Merck and Co., Inc., Rahway, N. J.

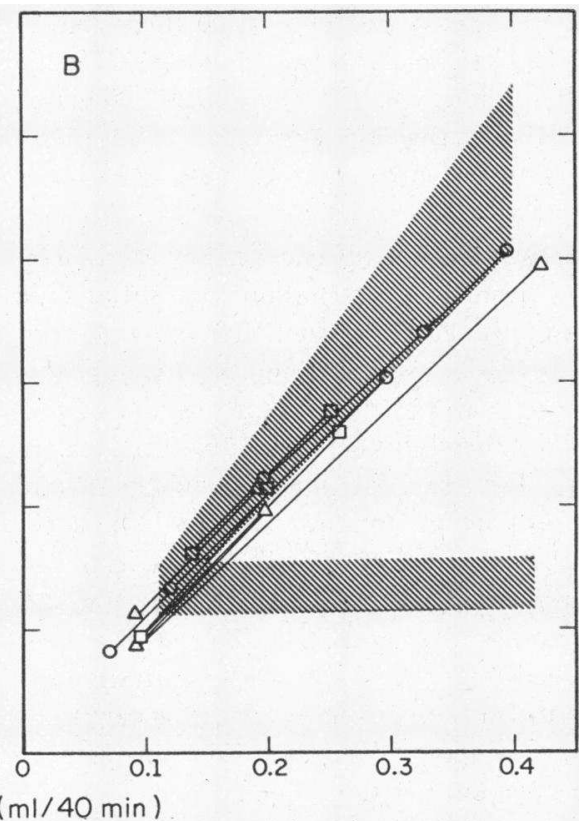

Figure $4 \mathrm{Na}_{\text {reab }}$ rate plotted against sweat rate. Data from Tables I and II. Shaded areas represent predicted trends with constant $\mathrm{Na}_{\text {reab }}$ rate (enhancement), and with a $\mathrm{Na}_{\text {reab }}$ rate proportional to increases in sweat rate (recruitment). These areas were calculated for the average sweat rate of the initial sample and for lowest and highest $[\mathrm{Na}]_{\mathbf{s w}}$. 
TABLE 1

Sweat Rate, Sodium Concentration, and Sodium Reabsorption during Sweating Induced by Total Heat Exposure

\begin{tabular}{|c|c|c|c|c|c|c|c|}
\hline \multirow[b]{3}{*}{$\begin{array}{l}\text { Exp. No. and } \\
\text { subject }\end{array}$} & \multirow[b]{3}{*}{$\begin{array}{l}\text { Skin area } \\
\text { and period }\end{array}$} & \multirow{2}{*}{\multicolumn{2}{|c|}{ Sweat data }} & \multicolumn{4}{|c|}{ Calculations } \\
\hline & & & & \multirow[b]{2}{*}{$\underset{\text { Nareab rate }}{C}$} & \multirow{2}{*}{$\frac{\frac{D}{A_{1}-A_{2}}}{A_{2}} \times 100$} & \multirow{2}{*}{$\frac{C_{1}-C_{2}}{C_{2}} \times 100$} & \multirow{2}{*}{$\begin{array}{r}F \\
E / D\end{array}$} \\
\hline & & $\begin{array}{c}\text { A } \\
\text { Volume }\end{array}$ & $\begin{array}{c}\mathrm{B} \\
{[\mathrm{Na}]_{\mathrm{sw}}}\end{array}$ & & & & \\
\hline \multirow{3}{*}{1 J. C. F. } & & $\mathrm{ml} / 40 \mathrm{~min}$ & $\mu E q / m l$ & $\mu E q / 40 \min$ & \multirow[b]{3}{*}{51} & \multirow[b]{3}{*}{49} & \multirow[b]{3}{*}{0.96} \\
\hline & Arm 1 & 0.121 & 27 & 14.3 & & & \\
\hline & 2 & 0.080 & 25 & 9.6 & & & \\
\hline \multirow{3}{*}{$\begin{array}{l}2 \\
\text { R. J. }\end{array}$} & Arm 1 & 0.174 & 21 & 21.6 & \multirow{3}{*}{26} & \multirow{3}{*}{29} & \multirow{3}{*}{1.11} \\
\hline & 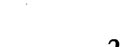 & 0132 & 24 & 167 & & & \\
\hline & 2 & 0.138 & 24 & 10.1 & & & \\
\hline \multirow{3}{*}{$\begin{array}{l}3 \\
\text { J. C. F. }\end{array}$} & Arm 1 & 0.134 & 35 & 14.7 & \multirow{3}{*}{84} & \multirow{3}{*}{81} & \multirow{3}{*}{0.96} \\
\hline & & & & & & & \\
\hline & 2 & 0.073 & 34 & 8.1 & & & \\
\hline \multirow{2}{*}{$\begin{array}{l}4 \\
\text { J. C. F. }\end{array}$} & $\mathrm{Abd}^{*} 1$ & 0.266 & 27 & 31.4 & \multirow[b]{2}{*}{15} & \multirow[b]{2}{*}{11} & \multirow[b]{2}{*}{0.73} \\
\hline & 2 & 0.231 & 22 & 28.4 & & & \\
\hline \multirow{3}{*}{$\begin{array}{l}5 \\
\text { G. T. }\end{array}$} & Abd 1 & 0.205 & 19 & 25.8 & \multirow{3}{*}{225} & \multirow{3}{*}{231} & \multirow{3}{*}{1.03} \\
\hline & & & & & & & \\
\hline & 2 & 0.063 & 21 & 7.8 & & & \\
\hline \multirow{3}{*}{$\begin{array}{l}6 \\
\text { J. C. F. }\end{array}$} & Abd 1 & 0.224 & 23 & 27.3 & \multirow{3}{*}{45} & \multirow{3}{*}{43} & \multirow{3}{*}{0.96} \\
\hline & & & & & & & \\
\hline & 2 & 0.154 & 21 & 19.1 & & & \\
\hline 7 & Thigh 1 & 0.118 & 35 & 13.0 & & & \\
\hline J. C. F. & 2 & 0.054 & 26 & 6.4 & 119 & 106 & 0.87 \\
\hline 8 & Thigh 1 & 0.311 & 36 & 33.9 & & & \\
\hline G. T. & 2 & 0.253 & 39 & 26.8 & 23 & 26 & 1.13 \\
\hline 9 & Thigh 1 & 0.161 & 25 & 19.3 & & & \\
\hline R. J. & & & & & 87 & 80 & 0.92 \\
\hline & 2 & 0.086 & 21 & 10.7 & & & \\
\hline
\end{tabular}

* Abdomen.

tight, plastic weighing bottles or Scotchpak aluminized polyethylene bags. For sweat collected with thermal and subdermally injected Mecholyl stimulation, three sites were located on one side of the body for collection: (a) forearm (superior third of the flexor side); (b) abdomen (supraumbilical region approximataely $4 \mathrm{~cm}$ below the point where the mammary line intersects the costal border); and (c) thigh (the upper third on the external surface). Only the forearm, however, was used for the training experiments.

The collection of sweat was divided into two $40 \mathrm{~min}$ periods for the thermal experiments, three $40 \mathrm{~min}$ periods for the subdermally injected Mecholyl experiments, and one daily 30 min period for the training experiments.

Analysis and protocol. The analysis of the sweat samples consisted of two analytical measurements. (a) The volume was calculated as the difference in weight of the plastic weighing bottles before and after the filter paper had ab- sorbed the sweat sample. (b) After the filter paper was dried in a vacuum oven at $50 \mathrm{~mm} \mathrm{Hg}$ and $70^{\circ} \mathrm{C}$, the salts were extracted by adding 4 or $5 \mathrm{ml}$ of a $0.01 \mathrm{~N} \mathrm{\textrm {LiNO } _ { 3 }}$ solution and mechanically shaking the weighing bottles up to $1 \mathrm{hr}$. The $[\mathrm{Na}]_{\mathrm{sw}}$ was then determined with a flame photometer (The U. S. Baird Corp., Stratford, Conn.) on lithium internal standard.

Blanks for the filter paper and recoveries of $\mathrm{NaCl}$ solutions were run in every experiment. From the recoveries, the standard error for the $\mathrm{Na}$ determination procedure was calculated and found to be $\pm 10 \%$. This is a rather large error since it includes not only the analytical error but others due to incomplete extraction of the salt, evaporation, dilution, etc. When the volume of sweat collected was below $0.03 \mathrm{ml}$, the analyses of the $\mathrm{Na}$ concentrations were discarded because the diluted concentrations were near the threshold 
of sensitivity of our apparatus and, thus, the error involved was too large.

\section{RESULTS}

Thermally induced sweat. $30 \mathrm{~min}$ after the subjects had entered the hot room, sweat was collected during two periods of $40 \mathrm{~min}$ each. Results presented in Table I show that the rate of sweating decreases during the second period and that of $[\mathrm{Na}]_{s w}$ usually does also. Recruitment in sample 1 was calculated from values of sample 2. The ratios between the per cent increase in $\mathrm{Na}$ reabsorption rate and the per cent increase in sweat rate ranged from 0.73 to 1.13. Ratio values above 1.00 indicate that the $\mathrm{Na}$ reabsorption rates increased more than the sweat rates. This effect could be produced if the sweat ducts of glands in population 2 were reab- sorbing $\mathrm{Na}$ below the $\mathrm{Tm}_{\mathrm{Na}}$ but at the maximal rate in population 1.

In Fig. $4 \mathrm{~A}, \mathrm{Nareab}$ rates were plotted against sweat rate for every pair of values in Table I. The shaded area represents the predicted trend for $100 \%$ recruitment or enhancement. It was calculated for an initial sample volume equal to the average of the experimental values and for two $[\mathrm{Na}]_{\mathrm{sw}}$, the lowest and the highest of this series. It can be observed that the slope of the lines joining the pair of observations approaches that calculated for total recruitment.

If $\mathrm{Na}$ excretion $(\mu \mathrm{Eq})$ of sweat for the data in Table $I$ is plotted against the sweat rate (Fig. 5), the experimental points can be compared with predicted lines for total recruitment and total enhancement. From these experiments, it appears that change in sweating under

TABLE II

Sweat Volume, Sodium Concentration, and Sodium Reabsorption during Sweating Induced by Subdermal Injection of Acetly- $\beta$-Methylcholine

\begin{tabular}{|c|c|c|c|c|c|c|c|}
\hline \multirow[b]{3}{*}{$\begin{array}{l}\text { Exp. No. and } \\
\text { subject }\end{array}$} & \multirow[b]{3}{*}{$\begin{array}{l}\text { Skin area } \\
\text { and period }\end{array}$} & \multirow{2}{*}{\multicolumn{2}{|c|}{ Sweat data }} & \multicolumn{4}{|c|}{ Calculations } \\
\hline & & & & \multirow[b]{2}{*}{$\begin{array}{c}\mathrm{C} \\
\text { Nareab rate }\end{array}$} & \multirow{2}{*}{ 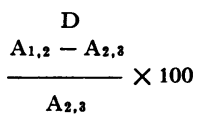 } & \multirow{2}{*}{$\frac{\stackrel{E}{C_{1,2}} \times C_{2,3}}{C_{2,3}} \times 100$} & \multirow{2}{*}{$\begin{array}{c}\text { F } \\
\text { E/D }\end{array}$} \\
\hline & & $\begin{array}{c}\text { A } \\
\text { Volume }\end{array}$ & $\begin{array}{c}\text { B } \\
{[\mathrm{Na}]_{\mathrm{sw}}}\end{array}$ & & & & \\
\hline \multirow{6}{*}{$\begin{array}{l}1 \\
\text { R. J. }\end{array}$} & & $\operatorname{ml} / 40 \min$ & $\mu E q / m l$ & $\mu E q / 40 \min$ & \multirow{4}{*}{22} & \multirow{4}{*}{18} & \multirow{4}{*}{0.82} \\
\hline & Arm 1 & 0.396 & 43 & 40.4 & & & \\
\hline & & & & & & & \\
\hline & 2 & 0.324 & 40 & 34.0 & & & \\
\hline & & & & & \multirow[t]{2}{*}{59} & \multirow[t]{2}{*}{52} & \multirow[t]{2}{*}{0.88} \\
\hline & 3 & 0.197 & 32 & 22.3 & & & \\
\hline \multirow{4}{*}{$\begin{array}{l}2 \\
\text { J. D. }\end{array}$} & Arm 1 & 0.297 & 42 & 30.6 & \multirow[b]{2}{*}{147} & \multirow[b]{2}{*}{114} & \multirow[b]{2}{*}{0.78} \\
\hline & & & & & & & \\
\hline & 2 & 0.120 & 26 & 14.3 & \multirow{2}{*}{64} & \multirow{2}{*}{72} & \multirow{2}{*}{1.12} \\
\hline & 3 & 0.073 & 31 & 8.3 & & & \\
\hline \multirow{4}{*}{$\begin{array}{l}1 \\
\text { R. J. }\end{array}$} & $\mathrm{Abd}^{*} 1$ & 0.258 & 45 & 25.8 & \multirow[b]{2}{*}{27} & \multirow[b]{2}{*}{21} & \multirow[b]{2}{*}{0.78} \\
\hline & ? & 0202 & 30 & 212 & & & \\
\hline & 2 & 0.200 & 37 & 21.0 & \multirow[t]{2}{*}{202} & \multirow[t]{2}{*}{195} & \multirow[t]{2}{*}{0.97} \\
\hline & 3 & 0.065 & 28 & 7.2 & & & \\
\hline \multirow{3}{*}{$\begin{array}{l}2 \\
\text { J. D. }\end{array}$} & Abd 1 & 0.252 & 38 & 27.0 & \multirow{3}{*}{84} & \multirow{3}{*}{69} & \\
\hline & & & & & & & 0.82 \\
\hline & 2 & 0.137 & 29 & 15.9 & & & \\
\hline 1 & Thigh 1 & 0.424 & 52 & 39.4 & & & \\
\hline R. J. & & & & & 123 & 101 & 0.82 \\
\hline & 2 & 0.190 & 42 & 19.6 & 102 & 108 & 1.06 \\
\hline & 3 & 0.094 & 45 & 9.4 & & & \\
\hline 2 & Thigh 1 & 0.194 & 32 & 21.9 & & & \\
\hline J. D. & & & & & 108 & 97 & 0.89 \\
\hline & 2 & 0.093 & 26 & 11.1 & & & \\
\hline
\end{tabular}

\footnotetext{
* Abdomen.
} 


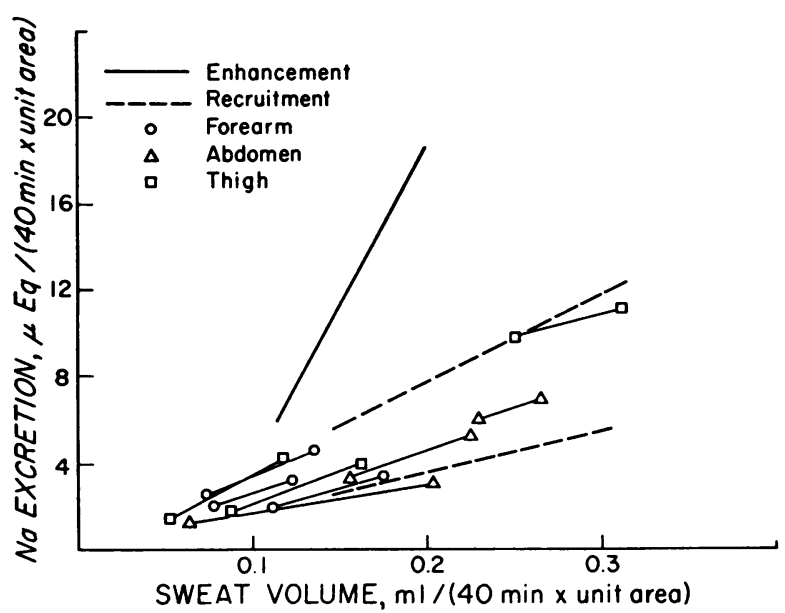

Figure 5 Summary of results of the experiments of Table I for thermally induced sweating. Two lines with different slopes were calculated for recruitment, one for a $[\mathrm{Na}]$ in sweat of $18 \mu \mathrm{Eq} / \mathrm{ml}$ and another for a $[\mathrm{Na}]$ of $39 \mu \mathrm{Eq} / \mathrm{ml}$. These are the lowest and the highest values found in this series. The slope of the lines joining the experimental points is close to that of the lines predicted for recruitment.

mild total body heat exposure is predominantly due to recruitment.

Sweating due to subdermally injected Mecholyl. A 3 $\mathrm{ml}$ solution of Mecholyl in isotonic saline $(200 \mu \mathrm{g} / \mathrm{ml})$ was injected subdermally and sweat collected immediately afterward during three periods of $40 \mathrm{~min}$ each. Table II shows that the sweat rate decreased from the first to the third collection period and that $[\mathrm{Na}]_{\text {sw }}$ was always the highest in the first sample. In two experiments the volume of sweat collected in the third period was too small for accurate analysis and discarded. Ratios for the per cent increase in sweat rates and $\mathrm{Na}_{\text {reab }}$ rates were calculated. The increase in the $\mathrm{Na}_{\text {reab }}$ rate in relation to the increase in sweat rate (recruitment) ranged in this series from 0.78 to 1.12 . The probable significance of values above 1.00 has been explained already.

In Fig. $4 \mathrm{~B}, \mathrm{Na}$ reab rates were plotted against sweat rates for the experiment in Table II. The shaded area was calculated as described above. The slope of the lines tends to be less than that calculated for $100 \%$ recruitment. That the trend of sweating for these experiments is still mainly recruitment, but involves some enhancement, can be seen if $\mathrm{Na}$ excretion is plotted against sweat rate (Fig. 6 ).

Sweat gland training. The data obtained from the training experiment of 18 days are presented in Figs. 7 and 8 . Compared with the 1 st day, the rate of sweating increased throughout the experiment while the Nareab rate remained about the same or even declined some-

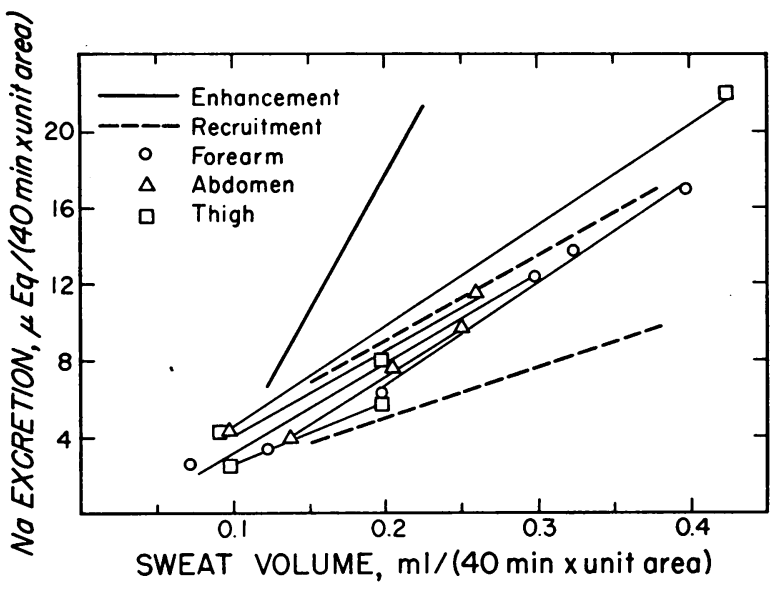

FIgURE 6 Summary of results presented in Table II for Mecholyl-induced sweating. The slopes of the lines joining the experimental points again predominantly coincide with that for predicted recruitment, although some tend toward enhancement.

what (Fig. 7). If $\mathrm{Na}$ excretion vs. sweat rate is plotted (Fig. 8), experimental points follow almost perfectly the theoretical lines for total enhancement.

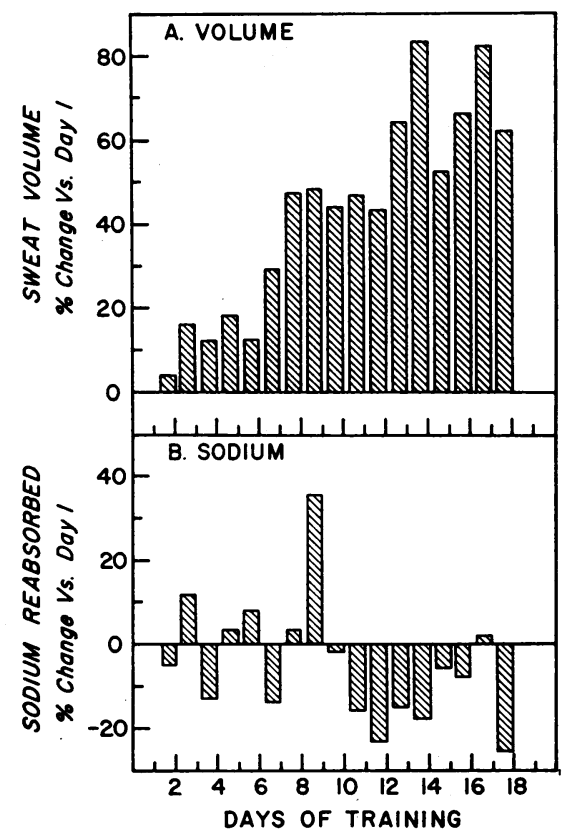

FIGURE 7 Effects of daily injections of Mecholyl for 18 days on measured sweat volume (A) and calculated reabsorption of sodium (B). Mean for two men and two women, both arms. Abscissa: days of training. Ordinate: change expressed as percentage of control day minus 100. Differences in volume between days 2 and 18 were significant at the 0.01 level. Differences in sodium were not significant at the 0.05 level.

Sweat Rate, Recruitment, and Enhancement 


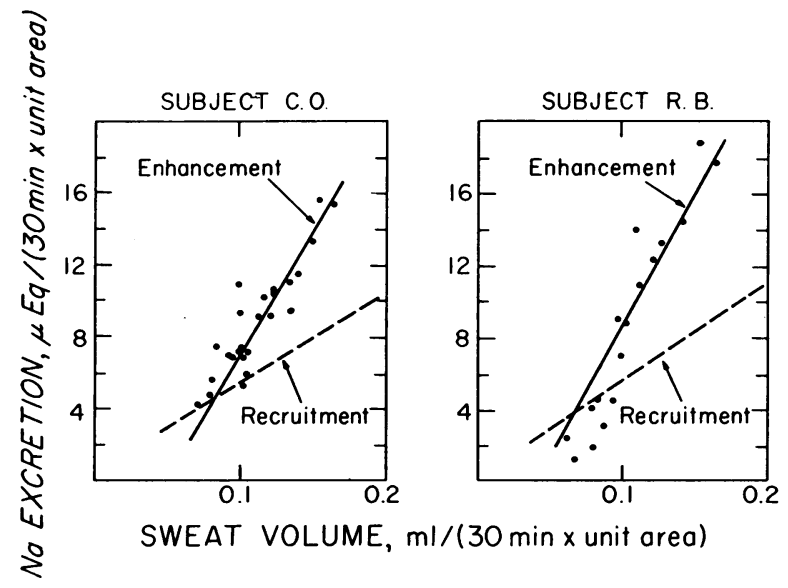

FIGURE 8 Relationship for $\mathrm{Na}$ excretion vs. sweat rate during training of the sweat glands by repeated daily intradermal injections of Mecholyl. The experimental points follow closely the predicted lines for total enhancement of glandular activity.

\section{DISCUSSION}

The observed results for the training experiment could occur if a progressively smaller number of glands were increasingly active in producing sweat. As the number of active glands decreased, the amount of $\mathrm{Na}$ reabsorbed, according to our hypothesis, would be expected to decline. Thus the increased volume of sweat may have resulted from the enhanced activity of the remaining active sweat glands. Alternately, it is possible that the number of active sweat glands did not change, but that repeated exposure to the intradermally injected Mecholyl in some way inhibited the ability of the gland to reabsorb $\mathrm{Na}$ while still enhancing its activity, resulting in an increased sweat volume. Certainly it is possible that the capacity to reabsorb $\mathrm{Na}$ by individual sweat glands may change from time to time due to metabolic, hormonal, or other factors. This course does not seem likely, however, since the diet, environmental, and other conditions were relatively constant throughout the experimental period. Still another possibility is that the daily intradermal injections of Mecholyl recruited only sweat glands of a very high $\mathrm{Tm}_{\mathrm{Na}}$, resulting in a homogeneous population. The latter possibility seems remote, however. In short, if the Nareab rate is a fair index of the number of sweat glands participating, the data on training indicate that the large increase in sweat volume, not accompanied by a proportional increase in $\mathrm{Na}$ reabsorption, was thus due predominantly to enhancement.

To calculate the contribution of recruitment to the increase in sweat rate, it was assumed that the initially active population was reabsorbing sodium at a maximal rate. According to the results of Cage and Dobson (1), this is achieved when the $[\mathrm{Na}]_{\mathrm{sw}}$ is around $20-30$ $\mu \mathrm{Eq} / \mathrm{ml}$. Most of the initial sweat samples in our experiments had a $[\mathrm{Na}]_{s w}$ within these limits. However, we must remember that these are mean values, and that groups of glands within the population sampled may be secreting sweat below or above the ductal reabsorption capacity for sodium. In the first case, any increase in sweat rate will be accompanied by an increase in the sodium reabsorption rate and will be computed as recruitment, as already explained. The second alternative, i.e. sweat secretion above the saturation point, will not alter the results since the $\mathrm{Nareab}$ rate will remain constant. Thus it is possible that values calculated for recruitment are too high, and conversely those for enhancement too low, depending on the actual value of $T \mathrm{~m}_{\mathrm{Na}}$ for the given population of sweat glands.

In considering sweating at different rates, we picture a given area of skin as having a fixed population of sweat glands, different groups having different thresholds for the mediator. At a given weak stimulus some would become active, others remain inactive. At some strong stimulus all would become active. Finally, above this stimulus level, further increase in sweat rate would be possible only by increased activity of already active glands. This hypothesis suggests that at low rates of sweating, recruitment is the predominant feature of changes in rate, whereas at high rates enhancement becomes the predominant feature.

In the experiments of Cage and Dobson (1), the sweat rate (forehead) increased from 3 to 10 times as shown in their Table I. From this table we calculated the Nareab rates; they showed increments ranging from 80 to $322 \%$. The increase in Nareab was smaller in every case than the increase in sweat rate; thus the ratio between both varied from 0.24 to 0.38 . This would indicate that in the experiments of Cage and Dobson the increase in sweat rate was brought about mostly by enhancement of the rate of secretion of the already active units (62$76 \%$ of the rate). This difference with our own observations most probably depends on the higher rates of sweat induced by them.

\section{ACKNOWLEDGMENTS}

Assistance from the University of Illinois Research Board, the National Aeronautics and Space Administration, and the National Science Foundation is acknowledged.

\section{REFERENCES}

1. Cage, G. W., and R. L. Dobson. 1965. Sodium secretion and reabsorption in the human eccrine sweat gland. J. Clin: Invest. 44: 1270.

2. Schulz, I., K. J. Ullrich, E. Frömter, H. Holzgreve, A. Frick, and U. Hégel. 1965. Mikropunction und electrische Potentialmessung an Schweissdrüsen des Men- 
schen. Pfluegers Arch. Gesamte Physiol. Menschen Tiere. $284: 360$.

3. Slegers, J. F. G. 1964. The mechanism of sweat secretion. Pfluegers Arch. Gesamte Physiol. Menschen Tiere. 279: 265 .

4. Brusilow, S. W. 1963. Determination of sweat gland precursor fluid osmolality by cryoscopy. J. Clin. Invest. 42: 920. (Abstr.)

5. Adams, R., R. E. Johnson, and F. Sargent II. 1958. The osmotic pressure (freezing point) of human sweat in relation to its chemical composition. Quart. J. Exp. Physiol. Cog. Med. Sci. 43: 241.

6. Bulmer, M. G., and G. D. Forwell. 1956. The concentration of sodium in thermal sweat. J. Physiol. (London). 132: 115 .

7. Gibson, L. E., and P. A. diSant'Agnese. 1963. Studies of salt excretion in sweat. Relationships between rate, conductivity and electrolyte composition of sweat from patients with cystic fibrosis and from control subjects. J. Pediat. 62: 855
8. Schwartz, I. L., and J. H. Thaysen. 1956. Excretion of sodium and potassium in human sweat. J. Clin. Invest. 35: 114.

9. Slegers, J. F. G. 1963. The mechanism of eccrine sweat gland function in normal subjects and in patients with mucoviscoidosis. Dermatologica (Basel). $127: 242$.

10. Fasciolo, J. C., G. L. Totel, and R. E. Johnson. 1969. Antidiuretic hormone and human eccrine sweating. J. Appl. Physiol. 27: 303.

11. Schwartz, I. L., J. H. Thaysen, and V. P. Dole. 1953. Urea excretion in human sweat as a tracer for movement of water within the secreting gland. J. Exp. Med. 97: 429.

12. Robinson, S., and A. H. Robinson. 1954. Chemical composition of sweat. Physiol. Rev. 34: 202.

13. Gordon, R. S., Jr., and G. W. Cage. 1966. Mechanism of water and electrolyte secretion by the eccrine sweat gland. Lancet. 1: 1246.

14. Collins, K. J., G. W. Crockford, and J. S. Weiner. 1966. The local training effect of secretory activity on the response of eccrine sweat glands. J. Physiol. 184: 203. 